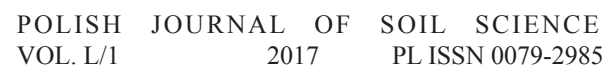

DOI: $10.17951 / \mathrm{pjss} / 2017.50 .1 .11$

\title{
IHOR PAPISH*
}

\section{DIFFERENTIATION OF THE MATERIAL COMPOSITION OF LVIV REGION LUVIC GREYZEMIC CHERNOZEMS (UKRAINE)}

\begin{abstract}
The soil formation within the Wet Atlantic Chernozem facies of the West-Ukrainian region leads to the vertical redistribution of Chernozem soil substance and formation of the differentiated mineral soil profile to varying degrees by carbonates, clay, and chemic-mineralogical composition. Luvic Greyzemic Chernozems (Siltic, Aric, Pachic) is characterized by the sharp differentiated profile by clay. The degree of vertical differentiation of clay profile is directly proportional to the intensity of the processes of leaching and gleyzation. In mineral profiles of Luvic Greyzemic Chernozems the vertical redistribution of clay material is mainly due to fraction smaller than $0.02 \mu \mathrm{m}$. The opposite character of profile distribution of mica-smectite and illite phases of clay minerals was discovered. Against the unbalanced losses of a part of clay plasma in the humus horizon, the process of relative illitization was detected due to smectite eluviation and accumulation of illite, kaolinite and finely dispersed quartz.
\end{abstract}

Keywords: Luvic Greyzemic Chernozems, clay fraction, chemical composition, loess-like loams, leaching, lessivage

\section{INTRODUCTION}

Within Lviv region, Luvic Greyzemic Chernozems cover the area of 90.8 thousand hectares (63.9 thousand ha - arable lands), that constitutes $4.1 \%$ of the total region area (WRB for Soil Resources 2014). In the Ukrainian soil classi-

* Ivan Franko National University of Lviv, Department of Soil Science and Soil Geography, P. Doroshenko 41 St. 41, 79000 Lviv, Ukraine. 
fication this soil is called the Podzolic Chernozem (Polupan et al. 2005). The index of agricultural use of this soil is high and totals $75.2 \%$ (Olenchuk and Nykolyn 1969). Lviv Region Luvic Greyzemic Chernozems together with Luvisols and Luvic Phaeozems form complex combinations (variations) allowing them to higher and more dissected positions of the relief (Andryushchenko et al. 1981). These Chernozems have been formed on the carbonate and non-carbonate loess-like loams of various genesis (Bogutskii 1986).

Traditionally, Chernozems are ranked as undifferentiated by the material composition of soil (Dobrovolskii 2012). Under conditions of circulation of hydrocarbonate-calcium solution in Chernozems, its aggressiveness is bare enough to wash out and redistribute calcium carbonates in the soil profile. At the same time, soil processes that actively destroy and redistribute the silicate part of the mineral composition of Luvic Greyzemic Chernozems seem not to take place (such as podzolization) or are slightly noticeable (gleyzation, lessivage, mole draining) (Medvedev and Laktionova 2003, Medvedev 2014). In general terms, these statements are true only for Haplic Chernozems (Loamic, Aric, Pachic) of wet Atlantic facies, but not typical for their leached and podzolized analogues (Papish et al. 2016). Due to humid climate of the facies, deep leaching of the carbonates, acidic environment, recovery processes and phenomena which occur periodically in different parts of the soil profile, including humus horizon, the profile of Chernozems is differentiated not only according to granulometric but also chemical and mineralogical composition. The nature of this phenomenon is complex and has different effects under different environmental conditions and at the various stages of soil formation (Lisetskii et al. 2013, Papish 2013).

\section{MATERIALS AND METHODS}

The object of the research is the chemical, mineralogical and granulometric profiles of regraded and hydrogenic-metamorphosed Luvic Greyzemic Chernozems (Siltic, Aric, Pachic) of an ordinary type (further in the text just as Chernozems). The soil has got a profound humus horizon (more than $70 \mathrm{~cm}$ ) and it was formed on loess loams (with the light and medium granulometric composition) of the watershed facies of Socal Plateau, Pobuggia Range, San-Dniester Upland and Lviv Plateau. Humid climate of the facies facilitates deep soil leaching (deeper than 170-180 $\mathrm{cm}$ in the ordinary kind), development of the processes of profile gleyzation and differentiation of the mineral composition. Soil profiles alternate in the southern direction from Volyn erosion upland in the north of the region, and in the south - towards the Dniester.

For high quality diagnostics of the differentiation processes of the mineral profiles of the studied Chernozems, the whole complex of general and special methods for quantitative analysis of soil were employed. Among them 
we applied such methods as: gross chemical composition of the soil and clay fraction by gravimetrical method (Arinushkina 1970); granulometric analysis by pipette method in modification of Kachinskii with pretreatment of soil by $4 \%$ solution of pyrophosphate $\mathrm{Na}\left(\mathrm{Na}_{4} \mathrm{P}_{2} \mathrm{O}_{7}\right)$ (Vadyunina 1986); $\mathrm{CO}_{2}$ carbonates determined by the Geisler-Maksymyuk method.

The orientated preparations were arranged by the sedimentation of the fraction onto cover glasses. X-ray diffraction was performed on a Philips X'Pert APD difractometer (with a RW 1870 generator and a PW 3020 vertical goniometer) at $40 \mathrm{kV}$ and $30 \mathrm{~mA}$ using $\mathrm{Cu} K_{\alpha}$ radiation in the Jagiellonian University in Kraków, Poland. The measurements were performed in the angle range of $2-52^{\circ}$ at a scan speed of $0.02 \%$. The preparations were analyzed in the air-dray state (Na-form) after saturation with ethylene glycol vapor.

Moreover, the direct-comparison method, stable component method and eluvio-accumulative component method were applied to evaluate the differentiation coefficient of the soil mineral matter (Rode 1971, Kit 2008).

\section{RESULTS}

The mineral part of Chernozems consists of silicates and aluminosilicates, metal oxides, simple salts and organo-mineral complexes. $\mathrm{SiO}_{2}, \mathrm{Al}_{2} \mathrm{O}_{3}, \mathrm{Fe}_{2} \mathrm{O}_{3}$, $\mathrm{CaO}, \mathrm{MgO}$ i $\mathrm{K}_{2} \mathrm{O}$, which are the components of primary and secondary minerals, particularly clay minerals, predominate among the chemical elements of the soil solid phase (Table 1).

The chemical profile of Lviv region Chernozems is typical for weakly-podzolized soils of the wet Atlantic facies. The gross chemical composition of such Chernozems is characterized by the high content of silica in the soil $(83-86 \%)$ and the low content of this element in the clay (56-59\%). The amount of sesquioxides $\left(\mathrm{R}_{2} \mathrm{O}_{3}\right)$ does not exceed $10-12 \%$ in regraded and $7-10 \%$ in ordinary types. Humus horizons are slightly enriched with silica and aluminum, and, at the same time, they lack in alkali and alkaline earth metals as well as the sesquioxides $\mathrm{Fe}_{2} \mathrm{O}_{3}$. Such character of the profile distribution of the basic metals is the result of weak processes of eluviation (decalcination, lessivage, podzolization process and feroliz) against the background of an intense in magnitude and depth a humus accumulative process. The wide molar ratio of $\mathrm{SiO}_{2}$ to $\mathrm{Fe}_{2} \mathrm{O}_{3}$ and $\mathrm{Al}_{2} \mathrm{O}_{3}$ in the humus horizon, compared to parent rock, is the evidence of active eluviation processes. The most illustrative is the molar ratio $\mathrm{SiO}_{2}: \mathrm{Fe}_{2} \mathrm{O}_{3}$ that indicates the dominant role of iron compounds in the eluviation processes of the mineral part of the profile.

The negative values of eluvio-accumulative coefficients of Chernozems show that basic oxides are leached from genetic horizons and the profile - in general - of almost all Chernozems. The exception from the general rule is 


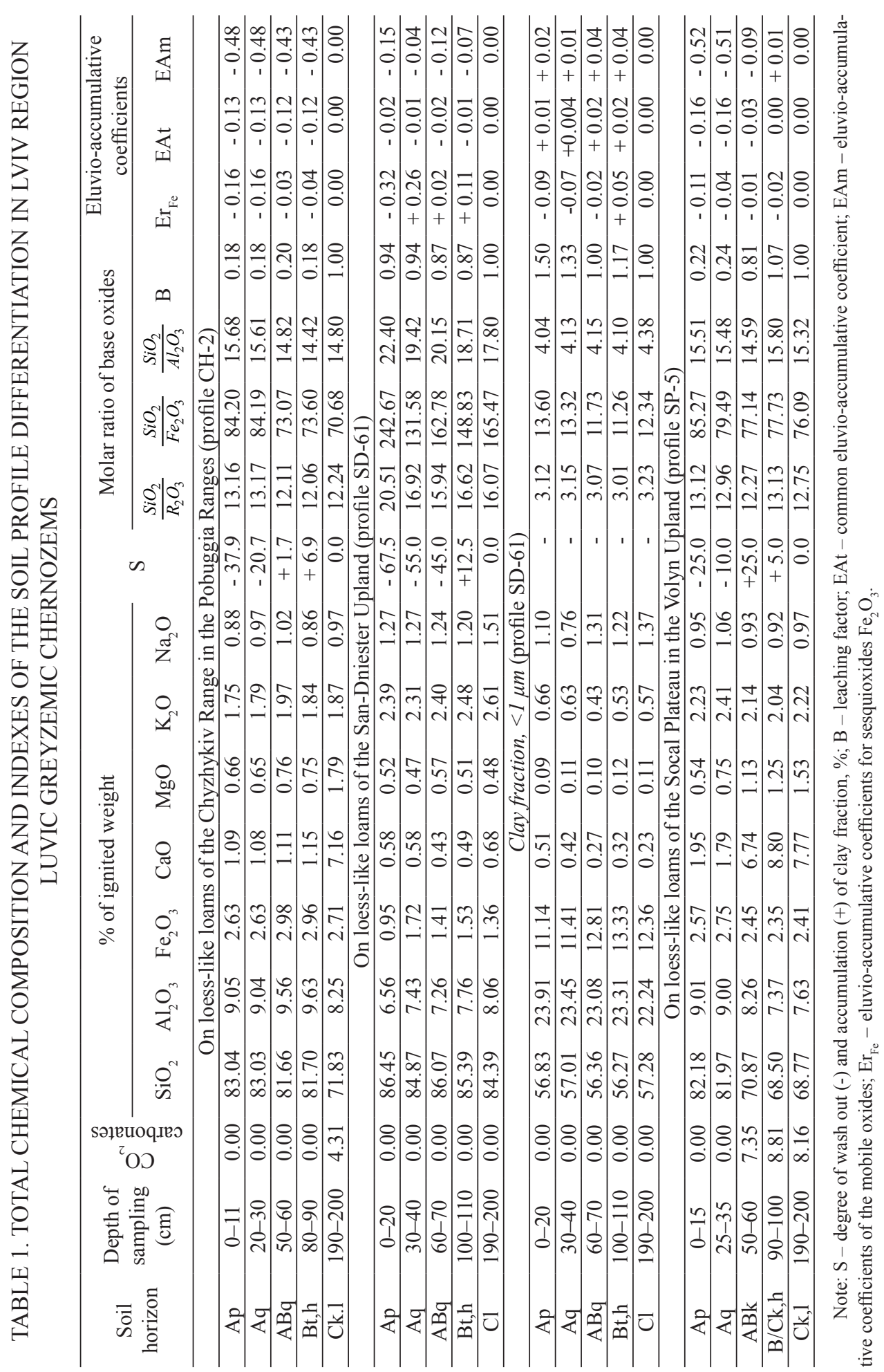


hydrogenic-metamorphosed Chernozem of the San-Dniester Upland (profile SD-61). Due to intense profile gleyzation, the sesquioxides $\mathrm{Fe}_{2} \mathrm{O}_{3}$ are accumulated in the fine earth fraction (particles size less than $1 \mathrm{~mm}$ ) below the arable layer while the rest of oxides are leached. In the clay fraction of the soil the situation is quite the opposite.

The mineralogical composition of the Chernozems fraction of less than $1 \mu \mathrm{m}$ is represented by the disordered mixed-layered formations of illite and smectite packets with dominance of the latter. The amount of this component within the Chernozems profile of the San-Dniester Upland ranges from 36\% to $54 \%$ with a minimum in the medium and the most podzolized part of the profile. In the depth of 70-80 cm, the percentage of hydromicas packets in the mixed-layered formation significantly increases. In the humus horizon $(A+A B)$ illite prevails (46-51\%) but its amount significantly decreases with the depth. The upper part of the profile is characterized by the high content of kaolinite (up to $13 \%$ ) with a small admixture of chlorite. Fine-dispersive quarts is found throughout the whole clay profile, while potassium field spars and plagioclases are present in the horizon $\mathrm{He}$ and they are not found in the clay fraction of the horizons situated beneath. Within the clay profile distinctive differentiation by the ratio of the main mineral phases is evident in the humus horizon and lower than $70 \mathrm{~cm}$ (Papish et al. 2016).

The podzolization and gleyzation processes led to the destruction of the smectite component in mixed-layered mica-smectite formations (high content of smectite packets) and relative accumulation of dioctahedral hydromica, kaolinite, chlorites, fine-dispersive quartz, potassium feldspars and plagioclases in this part of the profile. The mica-smectite layered silicates rich in smectite packets (a swelling phase) suffered the greatest destruction in the humus horizon. Moreover, the maximum concentration of fine-dispersive quartz is found there.

The data of the mineralogical composition clearly correlate with the results of total chemical analysis and morphological peculiarities of the studied Chernozems. In the upper part of the profile the amount of silicon and aluminium oxides increases. This shows that the proportion of silica and aluminium dioctahedral hydromica also increases. The simultaneous reduction of the content of iron sesquioxides and manganese oxide points to the destruction of magnesian-ferruginous chlorites and three-octahedral hydromicas while di-octahedral hydromicas which are more resistant to weathering are accumulated in this part of the profile. Also, the higher content of the gross potassium was determined and this can be seen as an indirect evidence of the hydrolysis processes in the humus horizon. The molar ratio $\mathrm{SiO}_{2}: \mathrm{Fe}_{2} \mathrm{O}_{3}$ slightly decreases in the Chernozems profile. This indicates the decomposition of the silicate part of the soils and movement of the decomposition products down the profile. This is the main but not the final cause of gleyzation of the illuvial part of the Chernozem profile. At the same time, the most expressive morphological signs of podzolization are 
found in the lower part of the humus horizon. The high content of phosphorus in the soil generally indicate its accumulation during the agricultural use and longterm use of manure, the clay fraction being the main reserve of its accumulation (Bryk et al. 2012, Papish 2013).

Thus, on the basis of the chemical and mineralogical composition of the studied Chernozems it can be concluded that in the process of soil formation a partial displacement of fine-dispersive colloidal particles occurs down the profile mainly due to the smectite component. Furthermore, weathering of the aluminosilicate part results in the formation of secondary minerals according to the following scheme: feldspars - micas - illite - mixed-layered formations. The relative accumulation of illite in the composition of clay material of the Chernozems humus horizon indicates the illitization processes of the mineral mass (Alekseev 2012).

The mineralogical composition of the fractions size of more than $1 \mu \mathrm{m}$ is represented by a complex of clastogenic minerals, among which the group of light minerals dominates, particularly quartz, feldspars, mica. The dominant mineral is quartz, especially in the fractions larger than $0.01 \mathrm{~mm}$ and its content equals $73-98 \%$. In the finer fractions the percentage of quartz decreases to 40-55\%. Feldspars are concentrated in medium- and fine-silt fractions. They are mainly represented by potassium feldspars (orthoclase, less often microcline). With depth the amount of feldspars and plagioclases increases (Andryushchenko et al. 1981). Such differentiation of feldspars in the profile is the result of the processes of intrasoil weathering, which is more intense in the upper part of the profile. Although there are only few mica minerals, they are concentrated in the silt fractions and represented chiefly by muscovite.

The granulometric composition of Chernozems is shown in Table 2.

\section{TABLE 2. THE GRANULOMETRIC COMPOSITION OF LVIV REGION LUVIC GREYZEMIC CHERNOZEMS}

\begin{tabular}{|c|c|c|c|c|c|c|c|c|}
\hline \multirow{2}{*}{$\begin{array}{l}\text { Soil horizon } \\
\text { (depth of } \\
\text { sampling, cm) }\end{array}$} & \multirow[b]{2}{*}{$\begin{array}{l}\text { Hygroscopic } \\
\text { moisture, \% }\end{array}$} & \multicolumn{7}{|c|}{ Size of soil particles in mm, quantities in $\%$} \\
\hline & & $1-0.25$ & $\begin{array}{r}0.25- \\
0.05 \\
\end{array}$ & $\begin{array}{r}0.05- \\
0.01 \\
\end{array}$ & $\begin{array}{l}0.01- \\
0.005\end{array}$ & $\begin{array}{r}0.005- \\
0.001 \\
\end{array}$ & $<0.001$ & $<0.01$ \\
\hline \multicolumn{9}{|c|}{ On loess-like loams of the Socal Plateau in the Volyn Upland (profile SP-1) } \\
\hline Ap $(0-30)$ & 1.7 & 0.00 & 8.8 & 66.8 & 3.6 & 8,8 & 12.0 & 24.4 \\
\hline ABt,q (38-48) & 2.2 & 0.00 & 7.6 & 59.6 & 8.4 & 4,8 & 19.6 & 32.8 \\
\hline $\mathrm{Bt}, \mathrm{k}, \mathrm{h}(65-75)$ & 2.2 & 0.00 & 12.0 & 57.6 & 10.4 & 3,2 & 16.8 & 30.4 \\
\hline \multicolumn{9}{|c|}{ On loess-like loams of the Chyzhykiv Range in the Pobuggia Ranges (profile CH-2) } \\
\hline Ap $(0-11)$ & 1.8 & 0.6 & 13.8 & 56.8 & 17.6 & 4.0 & 7.2 & 28.8 \\
\hline $\mathrm{Aq}(20-30)$ & 1.3 & 0.7 & 6.1 & 66.4 & 6.4 & 11.2 & 9.2 & 26.8 \\
\hline $\mathrm{ABq}(50-60)$ & 2.7 & 0.5 & 8.3 & 61.6 & 5.9 & 11.9 & 11.8 & 29.6 \\
\hline Bt,h (80-90) & 2.3 & 0.9 & 8.9 & 64.1 & 3.6 & 10.1 & 12.4 & 26.1 \\
\hline $\mathrm{B} / \mathrm{Ch}, 1(140-150)$ & 1.9 & 0.6 & 8.7 & 65.3 & 3.3 & 10.4 & 11.7 & 25.4 \\
\hline Ck,1 (190-200) & 1.5 & 2.0 & 8.6 & 65.8 & 4.8 & 7.2 & 11.6 & 23.6 \\
\hline
\end{tabular}




\begin{tabular}{|c|c|c|c|c|c|c|c|c|}
\hline \multirow{2}{*}{$\begin{array}{l}\text { Soil horizon } \\
\text { (depth of } \\
\text { sampling, } \mathrm{cm} \text { ) }\end{array}$} & \multirow{2}{*}{$\begin{array}{c}\text { Hygroscopic } \\
\text { moisture, \% }\end{array}$} & \multicolumn{7}{|c|}{ Size of soil particles in $\mathrm{mm}$, quantities in $\%$} \\
\hline & & $1-0.25$ & $\begin{array}{r}0.25- \\
0.05\end{array}$ & $\begin{array}{c}0.05- \\
0.01\end{array}$ & $\begin{array}{l}0.01- \\
0.005\end{array}$ & $\begin{array}{r}0.005- \\
0.001\end{array}$ & $<0.001$ & $<0.01$ \\
\hline \multicolumn{9}{|c|}{ On loess-like loams of the Lviv Plateau (profile LP-21) } \\
\hline Ap $(0-20)$ & 1.7 & 1.0 & 21.8 & 54.0 & 9.8 & 6.4 & 7.0 & 23.2 \\
\hline $\mathrm{ABq}(50-60)$ & 1.5 & 1.1 & 21.9 & 52.6 & 7.2 & 8.4 & 8.8 & 24.4 \\
\hline Bt,h,l (90-100) & 1.9 & 1.3 & 21.9 & 53.2 & 4.4 & 3.2 & 16.0 & 23.6 \\
\hline $\mathrm{B} / \mathrm{Cl}(125-135)$ & 2.0 & 0.9 & 25.3 & 47.8 & 4.0 & 3.2 & 18.8 & 26.0 \\
\hline $\mathrm{Cl}(190-200)$ & 2.0 & 0.1 & 28.3 & 48.0 & 4.0 & 4.6 & 15.0 & 23.6 \\
\hline \multicolumn{9}{|c|}{ On loess-like loams of the San-Dniester Upland (profile SD-61) } \\
\hline Ap $(0-20)$ & 2.5 & 0.0 & 10.0 & 60.8 & 14.4 & 9.6 & 5.2 & 29.2 \\
\hline $\mathrm{Aq}(30-40)$ & 2.3 & 0.0 & 10.0 & 60.8 & 12.8 & 9.2 & 7.2 & 29.2 \\
\hline $\mathrm{ABq}(60-70)$ & 1.6 & 0.0 & 12.8 & 60.4 & 7.6 & 10.4 & 8.8 & 26.8 \\
\hline Bt,h (100-110) & 2.2 & 0.0 & 11.9 & 60.0 & 4.9 & 5.2 & 18.0 & 28.1 \\
\hline $\mathrm{Cl}(190-200)$ & 1.9 & 0.0 & 7.2 & 60.8 & 10.4 & 5.6 & 16.0 & 32.0 \\
\hline \multicolumn{9}{|c|}{ On loess-like loams of the San-Dniester Upland (profile SD-41) } \\
\hline Ap $(0-20)$ & 2.3 & 0.0 & 14.4 & 56.4 & 9.2 & 12.0 & 8.0 & 29.2 \\
\hline $\mathrm{Aq}(30-40)$ & 2.0 & 0.0 & 15.2 & 48.4 & 15.6 & 12.4 & 8.4 & 36.4 \\
\hline $\mathrm{ABq}(50-60)$ & 1.9 & 0.0 & 13.6 & 51.8 & 12.6 & 12.8 & 9.2 & 34.6 \\
\hline $\mathrm{Bt}, \mathrm{h}(110-120)$ & 2.8 & 0.0 & 14.2 & 51.4 & 9.6 & 5.6 & 19.2 & 34.4 \\
\hline $\mathrm{Bt}, 1(150-160)$ & 2.6 & 0.0 & 14.4 & 49.2 & 10.4 & 8.0 & 18.0 & 36.4 \\
\hline $\mathrm{Cl}(190-200)$ & 2.6 & 0.0 & 15.8 & 48.6 & 13.2 & 6.4 & 16.0 & 35.6 \\
\hline
\end{tabular}

In the course of the long-lasting evolution of Chernozems and under the influence of the processes of humus accumulation, leaching, gleyzation, podzolization and lessivage, the regular changes in granulometric composition of soils have occurred. In addition, such composition of Chernozems derives from the parent rock. According to granulometric composition of Lviv region, Chernozems are mainly lightly loamy, less often medium loamy.

Chernozems inherited three peculiarities of their granulometric composition from loess rocks of Western-Ukrainian type. They are as follows: 1) a high content of sand fraction; 2) barely visible vertical lithological stratification, caused by difficult conditions of their sedimentation; 3 ) relatively low content of clay. Such lithological characteristics of loess deposits of Precarpathians and western Volyn-Podillya have clear geographical regularity. The most distinctively they are manifested in loess loams in Opillya and the San-Dniester Upland, and to a lesser degree, in the Sokal Plateau and the Pobuggia Range. In highly gleyed layers of parent rocks and in Chernozems of low above-alluvial land terraces with a slight increase of the amount of physical clay (fractions less than 0.01 $\mathrm{mm}$ ), the content of fine silt increases drastically, whereas the content of silt fraction decreases.

Chernozems have a strongly differentiated profile by clay regardless the natural region of their formation. This is illustrated by the high coefficient of the overall profile differentiation of more than 2.0 (Table 3 ). 
TABLE 3. THE OVERALL DEGREE OF THE LUVIC GREYZEMIC CHERNOZEMS PROFILE DIFFERENTIATION (S)

\begin{tabular}{|c|c|c|c|c|c|c|c|c|c|}
\hline \multirow{3}{*}{ Soil horizon } & \multirow{3}{*}{$\begin{array}{l}\text { Depth of } \\
\text { sampling } \\
\quad(\mathrm{cm})\end{array}$} & \multirow{2}{*}{\multicolumn{2}{|c|}{$\begin{array}{c}\text { Pobuggia } \\
\text { Range } \\
\text { (profile Ch-2) }\end{array}$}} & \multirow{2}{*}{\multicolumn{2}{|c|}{$\begin{array}{c}\text { Lviv Plateau } \\
\text { (profile LP-21) }\end{array}$}} & \multicolumn{4}{|c|}{ San-Dniester Upland } \\
\hline & & & & & & \multicolumn{2}{|c|}{ profile SD-41 } & \multicolumn{2}{|c|}{ profile SD-61 } \\
\hline & & Dv & $\mathrm{M}$ & Dv & $\mathrm{M}$ & Dv & $\mathrm{M}$ & Dv & $\mathrm{M}$ \\
\hline $\mathrm{A}$ & $0-40$ & 1.40 & 8.8 & 1.43 & 7.2 & 1.14 & 10.1 & 1.25 & 6.6 \\
\hline $\mathrm{ABq}$ & $40-70$ & 1.30 & 12.0 & 1.44 & 8.4 & 1.29 & 10.8 & 1.31 & 10.0 \\
\hline $\mathrm{Bt}, \mathrm{h}$ & $80-120$ & 1.50 & 17.4 & 1.60 & 18.8 & 1.55 & 19.9 & 1.50 & 17.5 \\
\hline $\mathrm{Cl}$ & $190-200$ & 1.60 & 11.6 & 1.63 & 15.0 & 1.64 & 16.0 & 1.62 & 16.0 \\
\hline $\mathrm{S}=\frac{P h i \times D v}{H e \times D v}$ & & 2.1 & & 2.6 & & 2.7 & & 3.2 & \\
\hline
\end{tabular}

Note: Dv - soil packing in the genetic horizon, $\mathrm{g} / \mathrm{cm}^{3} ; \mathrm{M}-$ the content of clay fraction $<1 \mu \mathrm{m}$ in the genetic horizon, $\%$.

The highest value of the differentiation (3.2) is in the hydrogenic-metamorphosed gleyed Chernozems and the least value is in the regarded analogues (less than 2.1). In the illuvial horizon, the increase of the clay fraction content often correlates with the increase of iron sesquioxides. However, clear differentiation of the profile does not always correspond to the degree of redistribution of clay and sesquioxides and is not evident in the chemical composition of the clay fraction. This can be explained by lessivage.

The texture differentiation of the Chernozems profile is caused not only by vertical redistribution of clay, which is supported by the data of chemical and mineralogical analysis, but also by the processes of intrasoil weathering and argillification in situ, which is proved by the data in Table 4 .

\section{TABLE 4. THE ARGILLIFICATION COEFFICIENT OF LVIV REGION LUVIC GREYZEMIC CHERNOZEMS}

\begin{tabular}{|c|c|c|c|c|c|c|c|c|c|c|c|c|}
\hline \multirow{3}{*}{$\begin{array}{l}\text { Depth of } \\
\text { sampling } \\
(\mathrm{cm})\end{array}$} & \multirow{2}{*}{\multicolumn{3}{|c|}{$\begin{array}{c}\text { Pobuggia Range } \\
\text { (profile Ch-2) }\end{array}$}} & \multirow{2}{*}{\multicolumn{3}{|c|}{$\begin{array}{c}\text { Lviv Plateau } \\
\text { (profile LP-21) }\end{array}$}} & \multicolumn{6}{|c|}{ San-Dniester Upland } \\
\hline & & & & & & & \multicolumn{3}{|c|}{ profile SD-41 } & \multicolumn{3}{|c|}{ profile SD-61 } \\
\hline & A & $\mathrm{B}$ & $\mathrm{C}_{\text {arg. }}(\mathrm{A}: \mathrm{B})$ & A & B & $\mathrm{C}_{\text {arg. }}(\mathrm{A}: \mathrm{B})$ & A & B & $\mathrm{C}_{\mathrm{arg}}(\mathrm{A}: \mathrm{B})$ & A & B & $\mathrm{C}_{\text {arg. }}(\mathrm{A}: \mathrm{B})$ \\
\hline $0-10$ & 0.38 & 0.47 & 0.81 & 0.32 & 0.64 & 0.50 & 0.44 & 0.45 & 0.98 & 0.28 & 0.50 & 0.56 \\
\hline $20-30$ & 0.34 & " & 0.72 & 0.29 & $"$ & 0.45 & 0.33 & & 0.73 & 0.21 & & 0.42 \\
\hline $40-50$ & 0.38 & $"$ & 0.81 & 0.31 & $"$ & 0.48 & 0.33 & 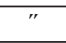 & 0.69 & 0.23 & 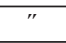 & 0.46 \\
\hline $60-70$ & 0.51 & " & 1.08 & 0.43 & " & 0.67 & 0.28 & $"$ & 0.62 & 0.33 & 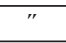 & 0.66 \\
\hline $70-80$ & 0.53 & $"$ & 1.12 & 0.45 & $"$ & 0.70 & 0.50 & $"$ & 1.11 & 0.52 & $"$ & 1.04 \\
\hline $90-100$ & 0.53 & $"$ & 1.12 & 0.68 & " & 1.06 & 0.57 & $"$ & 1.27 & 0.58 & $"$ & 1.16 \\
\hline $100-110$ & 0.56 & $"$ & 0.98 & 0.71 & $"$ & 1.11 & 0.58 & $"$ & 1.29 & 0.64 & $"$ & 1.28 \\
\hline $110-120$ & 0.56 & $"$ & 1.12 & 0.75 & $"$ & 1.17 & 0.56 & $"$ & 1.24 & 0.51 & $"$ & 1.02 \\
\hline $130-140$ & 0.60 & $"$ & 1.28 & 0.72 & $"$ & 1.13 & 0.46 & $"$ & 1.02 & 0.45 & $"$ & 0.90 \\
\hline $150-160$ & 0.46 & $"$ & 0.98 & - & $"$ & - & 0.49 & $"$ & 1.09 & 0.42 & $"$ & 0.84 \\
\hline $170-180$ & - & $"$ & - & 0.65 & $"$ & 1.02 & 0.51 & " & 1.13 & 0.39 & $"$ & 0.78 \\
\hline $190-200$ & 0.47 & 0.47 & 1.00 & 0.64 & 0.64 & 1.00 & 0.45 & 0.45 & 1.00 & 0.50 & 0.50 & 1.00 \\
\hline
\end{tabular}

Note: $\mathrm{A}-$ the ratio of the amount of clay fraction $(<1 \mu \mathrm{m})$ to the amount of physical clay $(<0.01 \mathrm{~mm})$ in the soil; $\mathrm{B}$ - the ratio of the amount of clay fraction $(<1 \mu \mathrm{m})$ to the amount of physical clay $(<0.01 \mathrm{~mm})$ in the parent material; $\mathrm{C}_{\text {arg. }}$ - coefficient argillification of soils. 
The argillification coefficient higher than 1.0 indicates the processes of argillification of the soil mass. Chernozems are characterised by the direct correlation between the intensity of the soil mass illuviation and the argillification coefficient. Therefore, the nature of the illuvial part of the Chernozems profile is much more complicated than mere mechanical illuviation of the soil mass by means of lessivage. The evidence of the differentiated profile by clay allows us to classify these Chernozems as the clay-illuvial Chernozem type.

\section{CONCLUSIONS}

The humus horizon of Luvic Greyzemic Chernozems is better enriched with silica and aluminium than the rock but, at the same time, it lacks alkali and alkaline earth metals, sesquioxides $\mathrm{Fe}_{2} \mathrm{O}_{3}$. In the soil, the process of removing of carbonates and basic oxides dominates over the process of their accumulation. This indicates the eluvial type of distribution of the mineral matter. The carbonate profile has an eluvial or eluvio-illuvial type distribution of carbonates. All in all, the Chernozems profile is the result of such processes as leaching, lessivage, podzolization and gleyzation, each of which dominated at different stages of formation and evolution of the soil.

The clay profile of Chernozems is differentiated by the correlation of the main mineral phases. The relative accumulation of dioctahedral hydromicas, kaolinite, chlorites and clastogenic minerals takes place due to removal of fine-dispersive smectite.

Chernozems have a strongly differentiated profile by clay. The texture differentiation of these Chernozems profile is caused not only by vertical redistribution of before colloidal fraction and colloidal clay but also by argillification in situ. By the nature of differentiation of the mineral matter, Lviv region Chernozems are classified as the clay-illuvial Chernozem variations.

The presence or absence of the podzolization in Luvic Greyzemic Chernozems (Silic, Arik, Pachic) of wet Atlantic facies of Ukraine is questionable. This problem cannot be denied but it cannot be too absolute either.

\section{REFERENCES}

[1] Alekseev, V.E., 2012. Sposob otsenki mineralogicheskogo sostoyaniya silikatnoy chasti chernozemov [Appreciated Method of the Mineralogical State of the Silicate Part in Chernozems]. Pochvovedeniye [Pedology], 2: 189-199.

[2] Andryushchenko, G.A., Bilskaya, M.V., Bilan, A.M., Voronoy, V.V., Sukharskaya, I.M., 1981. Chernozemy lesostepnoy zony Vlazhnoy atlanticheskoy fatsii [Chernozems of Forest-Stepper Zone of the Humid Atlantic Facies] Chernozemy SSSR (Ukraina) [Chernozems of the USSR (Ukraine)], Moscow: 80-95. 
[3] Arinushkina, E.V., 1970. Rukovodsnvo po khimicheskomu analizu pochv [Guide to Chemical Analysis of Soils], Moscow: $487 \mathrm{p}$.

[4] Bogutskii, A.B., 1986. Antropogenovye pokrovnye otloszeniya Volyno-Podolii [Anthropogenic Cover Deposits of Volyno-Podoliya] Antropogenovye otloszeniya Ukrainy [Anthropogenic Deposits of Ukraine], Kiev: 121-132.

[5] Bryk, M., Slowinska-Jurkewich, A., Medvedev, V.V., 2012. Morphometrical structure evaluation of long-term manured of Ukrainian Chernozem. International Agrophysics, 26: $117-128$.

[6] Dobrovolskii, G.V., 2012. Razvitiye ucheniya o chernozemakh v trudakh I. A. Krupenikova [Development of the Theory of Chernozems in the Works of I. A. Krupenikov]. Pochvovedeniye [Pedology], 12: 1008-1011.

[7] Kit, M.G., 2008. Morphologiya gruntiv [Soil Morphology], Lviv: 27-28.

[8] Lisetskii, F.N., Goleusov, P.V., Chepelev, O.A., 2013. Razvitiye Chernozemov Dnestrovsko-Prutskogo mezhdurechiya $v$ Holotsene [Development of Chernozems of the Dniester-Prut Interfluve in Holocene]. Pochvovedeniye [Pedology], 5: 540-555.

[9] Medvedev, V.V., Laktionova, T.N., 2003. Osobennosti phormirovaniya vertikalnykh vodnykh potokov $v$ chernozemye tipichnom [Features of the Formation of Vertical Water Flows in Haplic Chernozem]. Visnyk KhNAU [Bulletin of the KhNAU], 1: 37-43.

[10] Medvedev, V.V., 2014. Zmist $i$ zakonomirnosti antropogenovoyi evolyutsii gruntiv [The Contents and Laws of Soil Anthropogenous Evolution]. Gruntoznavstvo [Soil Science], 15, 1-2(24), Kyiv-Dnipropetrovsk: 17-32.

[11] Olenchuk, Ya., Nykolyn, A., 1969. Grunty Lvivskoi oblasti [Soils of Lviv Region], Lviv: 40-64.

[12] Papish, I. Ya., 2013. Valovyi khimichnyi sklad chornozemiv Sokalsko-Torchynskoi vysochyny [Gross Chemical Composition of the Sokal-Torchin Upland Chernozems]. Visnyk Lviv. Universytetu, Seriia Geographichna, Bulletin of the Lviv University, Geography Serious, 44: 265-274.

[13] Papish, I. Ya., Chizhikova, N.P., Poznjak, S.P., Varlamov, E.B., 2016. Clay Mineralogy in Agrochernozems of Western Ukraine. Eurasian Soil Science, 49, 10: 1161-1173.

[14] Polupan, M.I., Solovey, V.B., Velychko, V.A., 2005. Klasyficatsiya gruntiv Ukrainy [Ukraine Soil Classification], Kyiv: 300.

[15] Rode, A.A., 1971. Sistema metodov issledovaniya v pochvovedenii [The Systems of Research Methods in Pedology], Novosibirsk: 34-56.

[16] Vadyunina, A.F., 1986. Metody issledovaniya phizicheskikh svoyistv pochv [Research Methods of the Physical Properties of Soils], Moscow: 416.

[17] World Reference Base for Soil Resources 2014. International Soil Classification System for Naming Soils and Creating Legends for Soil Maps / World Soil Resources Report No. 106. FAO, Rome, 2014: 181, http://www.fao.org/3/a-i3794e.pdf (access: 10.05.2017). 